\title{
EEN DER VORMEN VAN HET SURINAAMSCHE LIED NA 1863 \\ DOOR
}

\section{Th. A. C. Comvalius}

In een vorig artikel hebben wij twee vormen van het Surinaamsche lied vóór 1863, de Banja en de Doe, beschreven, waarvan de begeleiding uitsluitend met inlandsche muziekinstrumenten geschiedt. De afschaffing der slavernij en de toenemende beschaving hebben niet nagelaten hun invloed op den inhoud en den vorm van het lied te doen gelden.

Als overgangsvorm van het Negerlied is er de Lobbie-Singie (letterlijk vertaald: het liefdeslied), dat naar den vorm tusschen het Afrikaansche en het Europeesche lied staat. Het Afrikaansch karakter is in zooverre erin behouden, dat het uit drieregelige verzen bestaat en door vrouwen wordt gezongen, terwijl de inhoud ervan uit haar wereld is afgeleid. Bovendien is het typisch verschijnsel van de beeldspraak erin behouden, en overheerschen Symecdochéen metonymia doorgaans in den tekst. De begeleiding geschiedt uitsluitend met Europeesche muziekinstrumenten, terwijl de melodie het Afrikaansch karakter bijna geheel verloren heeft. Ook de taal toont eenig verschil. Naast de zuiver Negerengelsche komen er in den tekst vaak woorden voor, die duidelijk hun Hollandsche afkomst verraden door vorm en beteekenis. De verzen hebben doorgaans den Jamben- of Anapesten vorm. Men vraagt zich dan ook af, hoe het mogelijk is, dat zich in een korte spanne tijds zulke veranderingen in het Surinaamsch lied hebben kunnen voltrekken bij de toen nog zeer gebrekkige volksontwikkeling.

Het antwoord op deze vraag vindt men in het volgende: Door of vanwege de Lobbie-Singie ontstonden sedert de laatste halve eeuw eigenaardige verhoudingen tusschen de vrouwen in Suriname, welke, in tegenstelling met den omgang onder mannen, niet verhinderd werden door het verschil in stand, ras of landaard. De liefde (?) bracht soms vrouwen van zeer uiteenloopende maat- 
schappelijke standen als intieme vriendinnen bij elkaar. Misschien is deze vorm van vriendschap eerder te beschouwen als een soort knechtschap van een der partijen, om niet te spreken van een andere, donkere, zijde ervan, waarvan de bespreking niet op onzen weg ligt.

Doch men kan uit het voorgaande afleiden, dat niet altijd degenen, die deze liederen voordroegen, op het auteurschap ervan kunen bogen. Er zaten andere, ontwikkelde, vrouwen achter de schermen, die niet misdeeld waren van kennis van de muziek.

$\mathrm{Al}$ is het dan minder sarcastisch dan de Doe, toch behield de Lobbie-Singie bij al zijn fijnheid en aardige melodie veelal den aard van het hekellied. De strekking van de Lobbie-Singie is, om den omgang tusschen vriendinnen, hare deugden en gebreken te bezingen. En aangezien er in de vrouwenwereld steeds meer krakeel heerscht dan onder de heeren der Schepping, zal het niet moeilijk vallen, den aard van sommige liederen te gissen. Het is vooral met het oog op dit laatste, dat men aan de Lobbie-Singie het dramatisch gedeelte van de Doe heeft toegevoegd. Zoodra namelijk een nieuw lied wordt voorgedragen, dat kwetsend is voor het subject, dat bezongen wordt, laat men „A-Flauw" optreden, de fee, in den persoon van een schoone vrouw, die door haar lied als het ware een pleister legt op de wonde, zoo even door de zangeres toegebracht.

De Lobbie-Singie is een openluchtspel, dat als regel des Zondags van 4 tot 7 uur in den namiddag vertoond werd. Er waren bepaalde punten in de volksbuurten van Paramaribo, waar het werd uitgevoerd. Zoo ligt aan de Saramaccastraat in de nabijheid van de Electrische Centrale een ruim perceel, dat vroeger grootendeels onbebouwd was en aan de Suriname-rivier grenst. Dit had vroeger toebehoord aan een Jood Abraham de Vries, die wegens zijn scheeven hals in den volksmond bekend stond onder den bijnaam „Abram kot nikkie”. De Vries vond zijn bestaan in het sloopen van afgekeurde koopvaardijschepen. Zijn perceel werd voor het grootste deel in beslag genomen door masten, kettingen, ankers, pompen, enz., afkomstig van die schepen, terwijl er een groote ruimte was vrijgelaten voor een handdraaimolen, toen de eenige in Paramaribo. Deze molen werd des Zondags van tien tot drie uur geëxploiteerd. Van vier tot zeven uur werd het terrein verhuurd aan de Lobbie-Singie voor drie gulden bij vooruitbetaling.

Het program van een Lobbie-Singie uitvoering bestond uit de volgende punten:

A. De langa-singie, de eigenlijke voordracht. Het is een episch-lyrische zang, het typisch kenmerk van het oorspronkelijke 
Surinaamsche lied. Er wordt een verhaal in neergelegd van het voorgevallene tusschen twee bepaalde vriendinnen. Deze „lange zang" is het hoofdpunt van de uitvoering, omdat hij altijd iets nieuws bevat, dat waard is, de aandacht van vrouwen te trekken. De belangstelling ervoor is ook beduidend. Want reeds dagen vooraf wordt het nieuws onder de vrouwen verspreid. dat vrouw A. haar vriendin of een andere vrouw zal bezingen. Deze kennisgeving drijft de nieuwsgierigen uit andere wijken naar de Saramaccastraat.

De toeschouwers vormen een grooten kring om de muzikanten en de zangeressen. Degenen onder deze laatsten, die een nieuw lied ter gehoore zal brengen, wandelt in statige houding en met langzamen tred in den kring, op den voet gevolgd door de overige deelneemsters. Ze zingt hare verzen één voor één voor, eerst zonder- en daarna met muziekbegeleiding, en herhaald door de overigen. Hier zien we weer een der kenmerken van het negerlied op den voorgrond treden: de reizang. De maat van de muziek wordt aangegeven door de zangeressen, die bonte hoofddoeken heen en weer zwaaien.

De inhoud en strekking van het lied, dat rijk is aan vernuftige zinswendingen, zijn door alle aanwezigen spoedig begrepen. En als blijk van instemming en waardeering wordt door het publiek aan de zangeres geld aangeboden, dat ze in een fraai bewerkt kanten zakje weglegt. Hier volgt een voorbeeld van een langa singie:
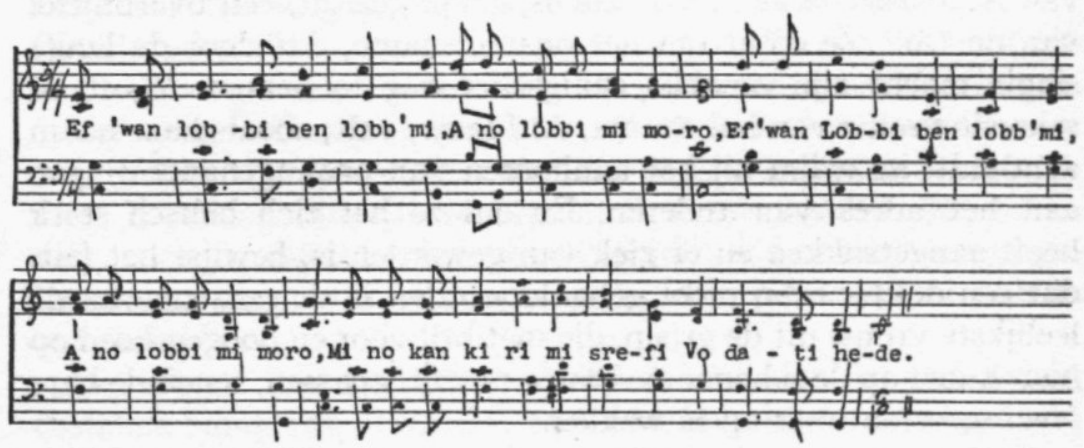

Vrij vertaald is de inhoud hiervan:

„Als een liefde (metonymisch gebruikt voor vriendin) mij eens heeft bemind, maar het thans niet meer doet, kan ik mijzelf hierom niet van het leven berooven."

B. De kot singie is een kort lied, uit één vers bestaande, dat als 
refrein na de langa singie wordt voorgedragen en eenige keeren met muziekbegeleiding herhaald. Gedurende de kot singie, waarbij ook gedanst wordt, houden de vrouwen, die in de laatste twee of drie weken nieuwe liederen hebben voorgedragen, zich gereed, om deze liederen te herhalen. Na haar zangen wordt telkens weer de kot singie herhaald.
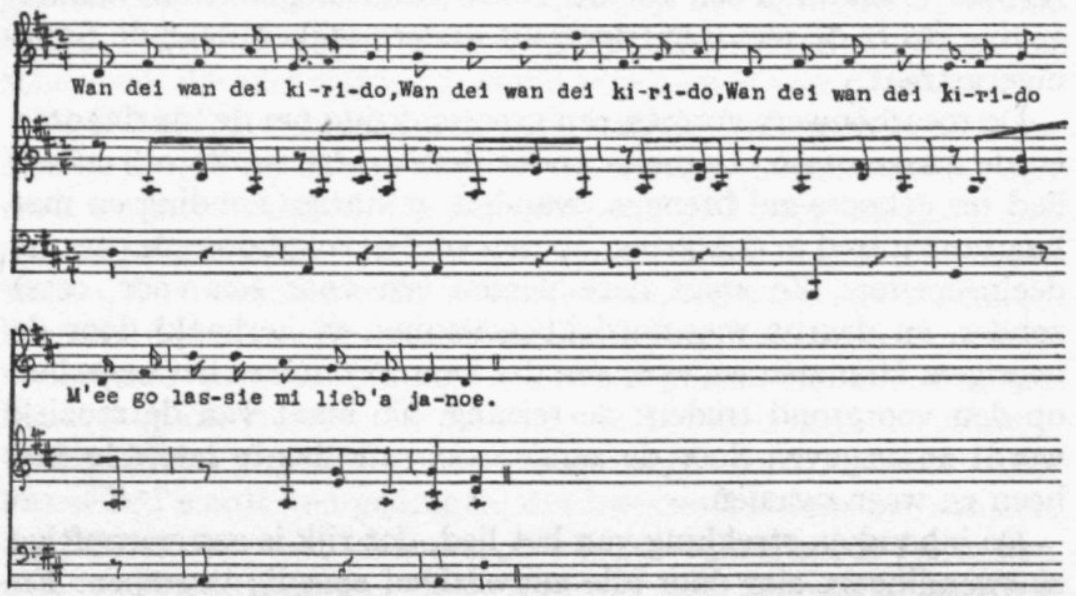

Deze kot singie is gewijd aan Cupido (kibido), den God der liefde.

C. Als slot van die uitvoering dient de dramatische voordracht van A. Flauw en de dokter. Dit is, gelijk gezegd, een overblijfsel van de Doe. Ze dient om het onaangename, dat door de langa singie mocht zijn verwekt, eenigszins weg te nemen. Want de schoone vrouw van het drama, A. Flauw, valt, zooals haar naam aanduidt, in zwijm bij het aanhooren van onaangename dingen aan het adres van anderen. En dat ze het zich heusch sterk heeft aangetrokken en er ziek van geworden is, bewijst het feit, dat een dokter erbij moet gehaald worden in de persoon van de leelijkste vrouw uit de groep, die met bril voor en hoogen hoed op haar kunst op de schoone A. Flauw moet toepassen, teneinde hare levensgeesten weer op te wekken.

De Openbare macht in Suriname zag zich omstreeks het jaar 1900 verplicht, om de lobbie singie voor eenigen tijd te verbieden, wegens een voorval, dat een geheele volkswijk gedurende langer dan een jaar in opschudding had gebracht.

Christiana Loloba was een volksdichteres en bevorderaarster van de lobbie singie, die in haar kring zeer gezien was. Om haar 
persoonlijk belang te dienen heeft zij een zoodanige verandering in de lobbie singie weten te brengen, dat langzamerhand mannen ervoor belangstelling begonnen te toonen. Zij was de huisvrouw van een eenvoudigen visscher, die door eigen vlijt en de spaarzaamheid van Christiana het tot een zekere mate van welgesteldheid had gebracht. Toen Sander zich rijk genoeg dacht en meende de hulp van Christiana te kunnen missen, liet hij deze met hun beide kinderen in den steek en koos zich een andere vrouw. Ze ontmoetten elkaar van toen af niet weer, tot het Kroningsfeest van onze Koningin in 1898 gevierd werd.

De Nationale feesten worden in Suriname uitbundig gevierd. En het feestterrein is de plaats, waar vele oud-bekenden elkaar ontmoeten. Dit was ook het geval met Christiana en Sander, die waarschijnlijk door de algemeene feestvreugde tot mildere gedachten jegens zijn verlaten vrouw was gebracht. Zijn poging, om zich met haar te verzoenen, bleef vruchteloos. En om hem aan de kaak te stellen nam zij haar toevlucht tot de lobbie singie, hetgeen de belangstelling van de mannen ervoor heeft opgewekt. Als de Zondagmiddag daar was, stroomden vrouwen en mannen, meest vrienden van Sander, naar de Saramaccastraat. En dat voor de verlaten vrouw openlijk door de andere visschers partij werd getrokken, bewees het feit, dat ze na haar voordracht ruime giften ontving, die haar in staat stelden in het onderhoud van haar kinderen te voorzien.

Spoedig lieten de visschers hun gewone roeiliedjes voor de Loloba-liedjes varen. Doch toen het lied: „Wan lage karakter” (Een laag karakter) door Christiana was gedicht, had dit vérstrekkende gevolgen. Op de volgende bladzijde volgt een der verzen.

Vertaling: „Een laag karakter (Sander) doet onderzoek naar mij, omdat hij mijn persoon niet ziet noch mijn naam hoort noemen. Hij dient echter te weten, dat ik steeds dezelfde ben gebleven in een versleten rok en een vuil jak; ik ben niet hooger geklommen, maar ook niet lager gedaald; mijn karakter heb ik behouden."

De verzen van dit lied beschrijven volledig de verhouding tusschen Sander en de vrouw, door wier hulp hij tot welstand was gekomen, doch die door hem op wreede wijze was verstooten.

De gevolgen bleven niet uit. De overige visschers spraken den boycot over Sander uit, die ten laatste geen knecht kon vinden, om met hem uit te varen, zeer ten nadeele van zijn bedrijf. En aangezien er langzamerhand door deze geschiedenis twee partijen waren ontstaan, die vaak met elkaar bloedige ontmoetingen had- 
den, moest de Openbare macht ingrijpen en Christiana het zwijgen opleggen.

De groote aantrekking van de lobbie singie verdween langzamerhand, aangezien Christiana niet langer op het tooneel verscheen. In onze dagen wordt deze vorm van het Surinaamsch lied zeer zelden gehoord.
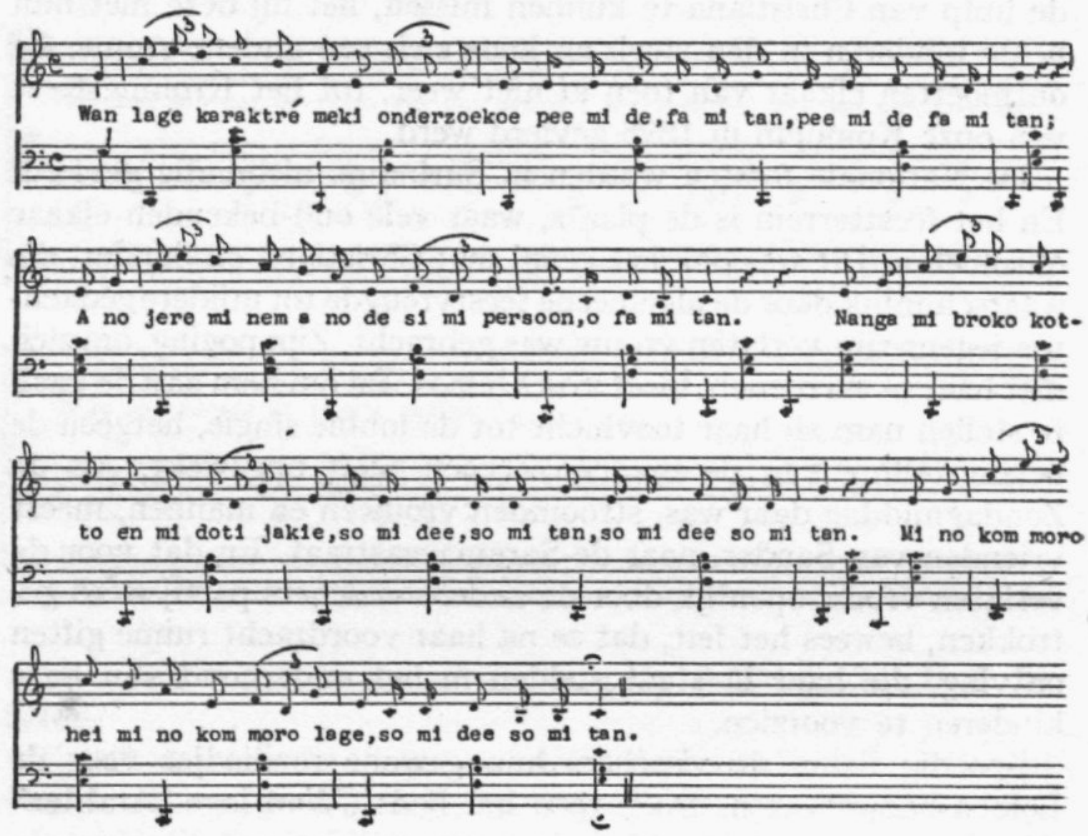